\title{
Student's Digital Literacy Abilities Against Hoaxes (A Case Study of University Students in East Kalimantan)
}

\author{
Rizky Amalia Syahrani ${ }^{1}$, Kheyene Molekandella Boer ${ }^{2}$ \\ \{syahranirizky@unukaltim.ac.id ${ }^{1}$, kheyenne.molekandella@fisip.unmul.ac.id² \\ Nahdlatul Ulama University of Kalimantan Timur, Jl. KH Harun Nafsi, Kalimantan Timur ${ }^{1}$, \\ Mulawarman University, Jl. Kuaro, Kalimantan Timur ${ }^{2}$

\begin{abstract}
Social media is now becoming the major needs in our society. The rapid flow of information has made the existence of hoaxes even more numerous and provocative. Literacy activities within university's environments in East Kalimantan are considered low so that students, as agent of change, are needed to fight hoaxes that occurs in the society. This study uses qualitative research by taking six informants from three different campuses. The results of the study show that the majority of informants decided not to share the news that they got when the source was not reliable enough.
\end{abstract}

Keywords: Hoax, Digital Literacy, Student

\section{Introduction}

The pattern of public information consumption has shifted over time. Alternative media are increasingly coloring the public's choices in seeking information. Since 2000, internet consumption behavior which initially focused on television platform began to shift to internetbased media. The internet now became the "it" item because of the facilities that it offers. For example, users can browse everything they want to find 24/7. Internet users also have full control to access over their routines to use the internet in which they do not have such control over a television.

\begin{tabular}{|c|c|c|c|c|c|c|}
\hline & 2013 & 2014 & 2015 & 2016 & 2017 & 2018 \\
\hline 1. China* & 620.7 & 643.6 & 669.8 & 700.1 & 736.2 & 777.0 \\
\hline 2. US"* & 246.0 & 252.9 & 259.3 & 264.9 & 269.7 & 274.1 \\
\hline 3. India & 167.2 & 215.6 & 252.3 & 283.8 & 313.8 & 346.3 \\
\hline 4. Brazil & 99.2 & 107.7 & 113.7 & 119.8 & 123.3 & 125.9 \\
\hline 5. Japan & 100.0 & 102.1 & 103.6 & 104.5 & 105.0 & 105.4 \\
\hline 6. Indonesia & 72.8 & 83.7 & 93.4 & 102.8 & 112.6 & 123.0 \\
\hline 7. Russia & 77.5 & 82.9 & 87.3 & 91.4 & 94.3 & 96.6 \\
\hline 8. Germany & 59.5 & 61.6 & 62.2 & 62.5 & 62.7 & 62.7 \\
\hline 9. Mexico & 53.1 & 594 & 65.1 & 70.7 & 75.7 & 80.4 \\
\hline 10. Nigeria & 51.8 & 57.7 & 63.2 & 69.1 & 76.2 & 84.3 \\
\hline 11. UK $\cdot *$ & 48.8 & 50.1 & 51.3 & 52.4 & 53.4 & 54.3 \\
\hline 12. France & 48.8 & 49.7 & 50.5 & 51.2 & 51.9 & 52.5 \\
\hline 13. Philippines & 42.3 & 48.0 & 53.7 & 59.1 & 64.5 & 69.3 \\
\hline
\end{tabular}

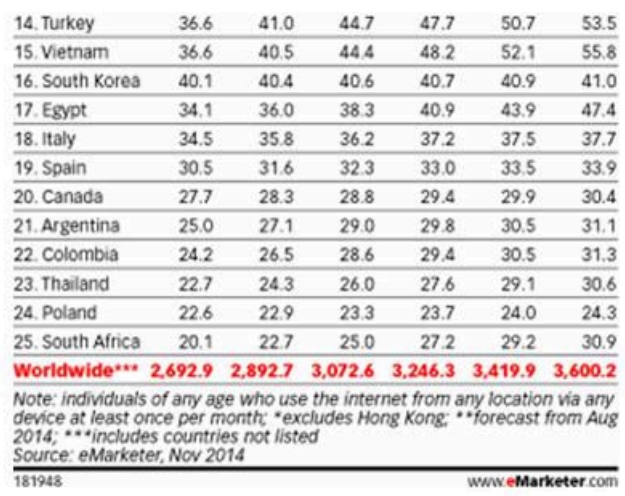

Figure 1. Indonesia ranked $6^{\text {th }}$ by internet users in 2013-2018 (www.eMarketer.com) 
Internet users in Indonesia are dominated by those aged from 19 to 34 years old or as much as $49.52 \%$. Then in the second position as much as $29.55 \%$ of internet users aged $35-54$ years old while in the lowest position, teenager $16.68 \%$ users aged $13-18$ years old [1]. This data shows that 19-34 years old is the largest age group using internet in carrying out their daily activities.

One of the products presented by social media was the emergence of fake news or hoaxes. Hoax is news with unclear source and truth, where hoaxes aim to create anxiety, panic, and a chaotic event for certain agendas and goals.

Teenager are often considered the agents of change, hence the quality of a nation in general can affect the quality of the next generation. Technology also plays a big role in determining the quality of the next generation. With the large access to information, the internet offers both benefits and harms when being used. We can call internet as threats for those who do not know how to handle it.

East Kalimantan also get the special "highlight" when most of the national news announcing it as the chosen capital city of Indonesia. This becomes a new challenge since East Kalimantan is chosen as the new capital city, the news traffic will also become more hectic and jammed. Therefore, educating teenager by using digital literacy is needed as soon as possible.

Media literacy [2] is a perspective when an individual is actively responding the media and describing the meaning of the message. Digital literacy activity in East Kalimantan is considered low as only few news agencies, communities, and universities that do the digital activities.

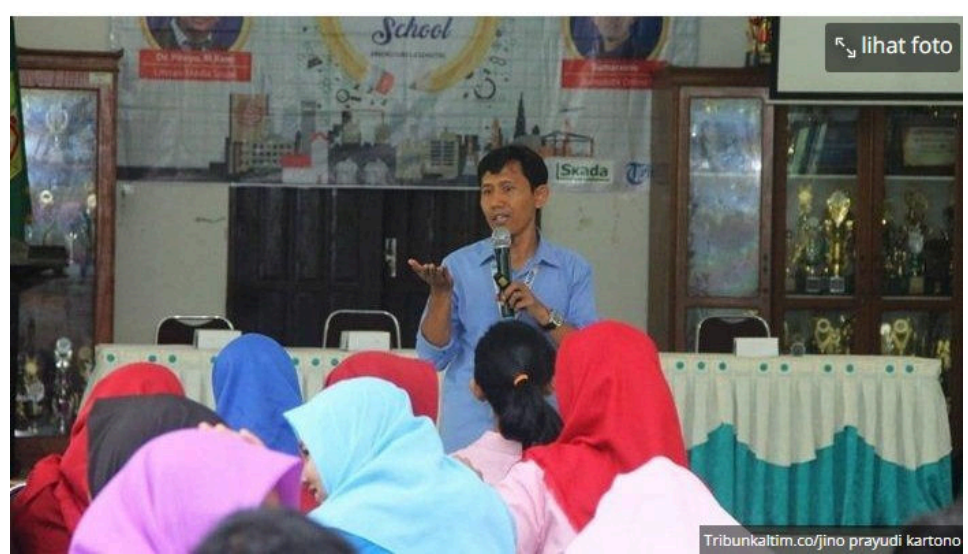

Figure 2. Literacy event from Tribun Kaltim Newspaper at Senior High School 2 Balikpapan Source: https://kaltim.tribunnews.com/2018/12/13/video-tribun-kaltimgoes-to-school-literasi-digital-cegah-hoax-di-smkn-2-balikpapan 


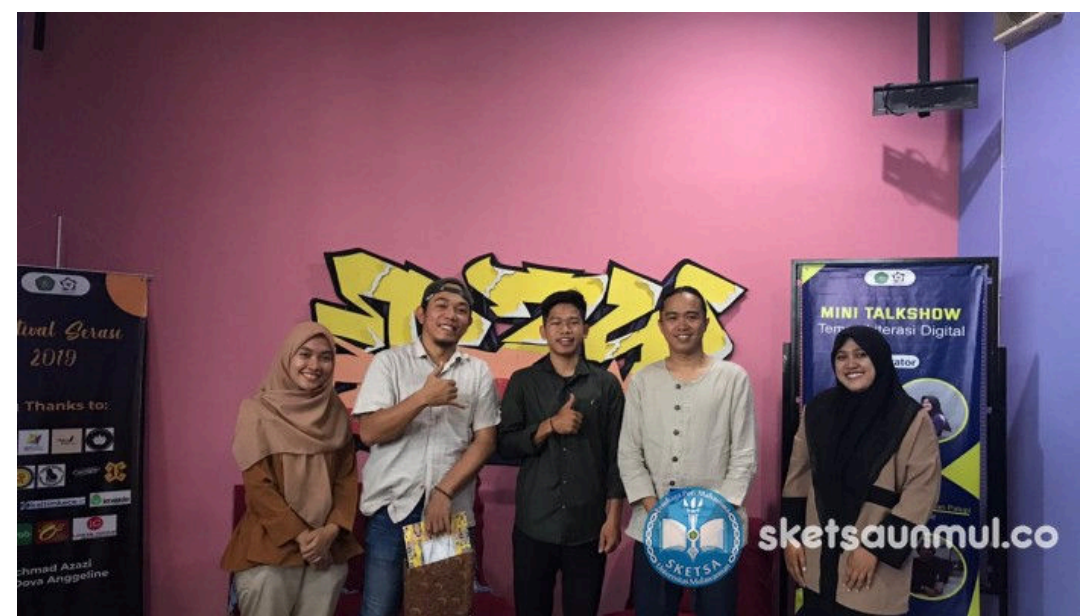

Figure 3. GenBi Indonesia Literacy Activities

Source: htts://www.sketsaunmul.co/event/menjelajah-literasi-digital-dalam-serasi/baca

The picture shows GenBi (Generasi Baru Indonesia or Indonesian New Generation Community) also actively do literacy activities in East Kalimantan. The goal is to educate citizens to be aware of hoaxes in social media. The researches about literacy education are also considered low in East Kalimantan which makes it hard to see how the literacy skills are developing in East Kalimantan.

This article is structured as follows. First, we discuss the concept of media literacy. Second, we provide an overview of the previous research about media literacy. Finally, we discuss the concept of media literacy ability that communication science students' have in East Kalimantan against hoaxes that are currently bombarding their social life every day. Students as the agent of change also have a big role to change the society by possessing the ability to receive information.

\section{Literature Review}

\subsection{Media Literacy and Hoaxes in Indonesia}

Literacy is an activity that aimed to train each person ability to choose media products or digital contents to have the best quality of information. James potter [3] states that media literacy is a perspective that we actively use when exposing ourselves to the media in order to interpret the meaning of the messages we encounter. We build our perspective from knowledge structures; thus, we need the tools and the raw material. The tools are our skills. The raw material is the information from the media and the world. Active use means that we are aware of the messages and are consciously interacting with them.

Literacy is an effective way to respond to the global condition nowadays. A lot of information that we have every second makes information seems overwhelming since we do not know its quality. Media digital power on sharing the information is also worrying, because most hoaxes shared in social media tend to create a harmful atmosphere and disrupt peace in the society

Media literacy also emphasizes the following elements [4]

1. Critical thinking skills that allow audience to develop independent judgments about media content;

2. An understanding of the process of mass communication; 
3. An awareness of the impact of media on the individual and society;

4. The development of strategies with which to discuss and analyze media messages;

5. An awareness of media content as a "text" that provides insight into our contemporary culture and ourselves;

6. The development of a greater enjoyment, understanding, and appreciation of media content; and

7. In the case of media developers, the ability to create effective and responsible media messages.

To have the ability in the media literacy the society needs to reinforce four key concepts [5]:

1. Appreciation of the power of reliable information and the importance of a free flow of information in a democratic society;

2. Understanding why news matters and why becoming a more discerning news consumer can change individual lives and the life of the country;

3. Understanding how journalists work and make decisions and why they make mistakes;

4. Understanding how the digital revolution and the structural changes in the news media can affect news consumers; understand our new responsibilities as publishers as well as consumers.

Hoax is information that is manipulated to hide the actual purpose or change the facts using information that looks promising but the truth is not able to be verified. Hoaxes are always shown to our social media dozens or hundreds of times a day, mostly on Instagram, Facebook, and WhatsApp groups. Everything is well-prepared and ready to serve to public with various responses.

A survey that MASTEL (Masyarakat Telematika Indonesia/Indonesian Telematics Society) did about hoaxes in 2019, respondents in Indonesia showed that about $34.6 \%$ respondents received hoaxes every day and $14.7 \%$ had at least one hoax a day. MASTEL also showed the media that are mostly used to share hoaxes are digital media like websites, chatting applications, and social media. [6]

Hartono (2018) in his article [7] tells us that hoaxes are related to post-truth phenomena where truth is not only based on the truth itself but based on subjectivity that includes the interest in politics, religions, organizations, etc.

This phenomena is now becoming the most important note to the communication technology in Indonesia. Indonesia as a developing country has always been open to new things. Technology existence is not only to give the good sides, but also a few things to learn for example the amount of hoaxes that spreading around easily.

\section{Research Method}

The research applies case-study as the method and it is carried out with these following steps:

The data collection is performed with in-depth interviews, observation, and literature review. The interview is conducted in a flexible, open and informal ways, without rig structure and able to be repeated to the informant. The questions are arranged with an interview guide and it becomes the priority in the interview process. After that, the guide can be expanded, developed, and modified for gaining deeper and unpredicted information. For accuracy, the answer will be written down [8]. The informants are chosen with purposive sampling method and criterionbased election. In this research, the informants are the students that currently enroll in communication science major at 3 biggest universities in East Kalimantan while the observation is conducting a focus group discussion and the literature review is conducted by analyzing 
various works of literature regarding media management. The data reduction in this research is the process of selection, simplification, and abstraction of the data taken from the interview record and field note. [9]

\section{Result and Discussion}

\subsection{Appreciation of the power of reliable information}

Most of the informants are using social media to find information, although a few sudents also read newspaper every day to fill their daily needs of information.

"I look out for more information on websites and read what is on social media such as, liputan6.com and cnn.com" (Informant Rini)

Most often, I read from Jawa Pos and Kompas. When I open online portals I prefer to find what news is currently viral on Twitter, like about Kartu Prakerja sometime ago where people can get 3 million monthly, sometimes I open several media for instance, detik.com, liputan6.com ..." (Informant Roro)

"I like to find news more on social media, I frequently read from Tempo's, Kaltim Post's Koran Kaltim's and detik.com's e-paper. For the local media, I favour to read Kaltim Post and Koran Kaltim since both have a good reputation and the news sources are trustworthy as far as I'm concerned. In television, I love watching Mata Najwa news. I'm no longer subscribing newspaper and if I have to read newspaper, I will read it in my campus" (Informant Aswin)

"I search for news from online media where it usually gives notifications. If I am interested, I will open what I consider verified. Usually I get news from Instagram but if it has not been verified, I am going to find the comparison in the social media or news program on television and when I do not find the suitable standards, I will watch anything shown in the channel I open" (Informant Hana)

"I always open Instagram first and after I open it and I want to ensure the clarity of a news, I will open YouTube. If I still do not get satisfied of my findings there, I will rely on other media such as, Google. As I switch on my television, the news will be broadcast in the morning or afternoon although it is published more often in the afternoon in Metro TV or SCTV where it is done the most frequently" (Informant Erika)

Three statements above showed that student's preference has moved to digital/online media. The function of printed media is still used but moving to digital media (by using e-paper from the same source). We can conclude that their preference on choosing the media is because of the easy access provided by their smartphone. As updating is the main character of new media, informants state that e-paper is much easier to use and more handier than the usual newspaper.

\subsection{Understanding why news matters}

Most hoaxes found at student's WhatsApp group and it is filled with chained messages which untraceable or any broadcast without reliable source. The informants showed knowledge of their media content, hoaxes and function that they had from the media itself:

"Normally, the way I verify fragments of news online is by looking out for more on other media first. Once I have clearer picture and understanding of what the news is about, I try to conclude it" (Informant Aswin)

"What I do to identify hoaxes is by going through other media. Afterwards, I will examine the structure and content of the news itself if it tends to be containing authorbased opinions or whatsoever so I cannot fully trust such news. When a news title is 
bombastic, I will look at it first and find the similar ones from other media" (Informant Aswin)

"When it comes to a broadcast news, typically there will be no sources stated, mam despite claiming that it comes from a ministry or agency yet there is no official sources written. If it truly is an official news, other media should have been doing the delivery instead of being broadcast. Unless there is an officially issued letter, I am not going to be sure it is valid. I also received a strange news about Covid. But since I found it odd, I did not share it" (Informant Fahmi)

Informant Aswin and Fahmi were identifying hoaxes by looking at the main source, then find the other reliable sources. Then conclude if the main source is real or not. Prasetyo [10], Head of Indonesian Press Council, says that hoaxes on social media often comes from news that is difficult to verify. Chained messages or broadcast messages received in social media which have unreliable source makes individuals directly digest the information because they think there is nothing wrong to protect themselves. The government also continues to strive to eradicate hoaxes circulating as an effort to educate the public to have the ability to analyze and consume news that is fit for the society.

\subsection{Understanding how media work and make decisions and why they make mistakes}

The types of hoaxes that circulating are differs. The form could be written texts, videos, images and many more. Various social media are also easy platforms for hoaxes to circulate. This study found various facts conveyed by informants about the dominating of the types of hoaxes that were circulating and which media had the most hoaxes.

"I found hoaxes the most on WhatsApp since in my opinion, it has the 'Share' feature" (Informant Roro)

"I found hoaxes mostly on Facebook and WhatsApp. Older women love using Facebook irresponsibly" (Informant Rini)

"On Facebook mam, although I rarely use it, I frequently found a lot of news what I thought was odd" (Informant Fahmi)

"I often received hoaxes in the form of text like the typical news circling around WhatsApp groups and Twitter. On Twitter, someone can share something from a website but it is not necessarily reliable therefore we, as the readers, found it strange and questionable" (Informant Hana) 


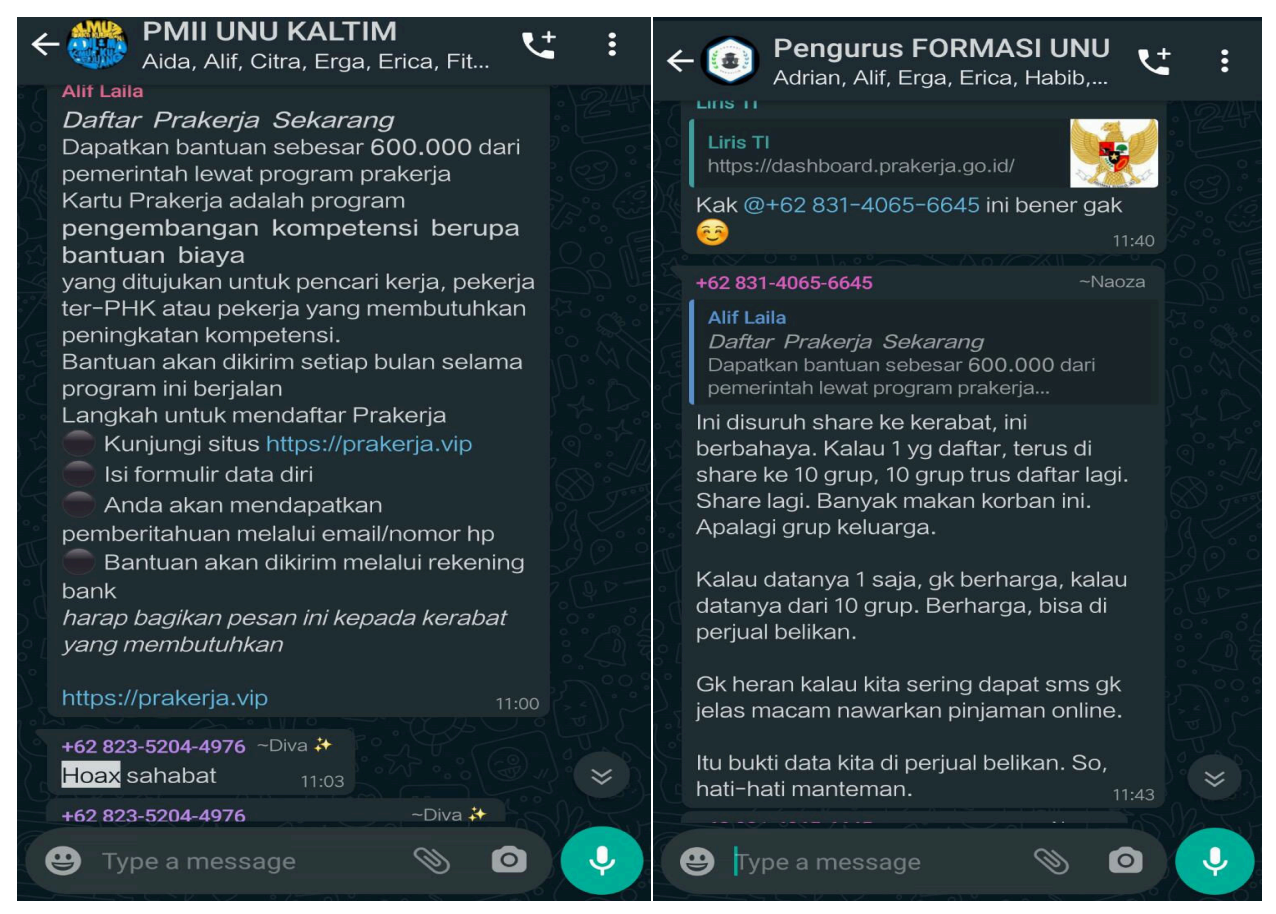

Figure 4: Hoaxes in A Student's community WhatsApp group

\subsection{Understanding how the digital revolution can affect the news consumer}

As we know that Facebook has more features such as like, comment, and share button that connect bigger societies to reproduce any messages. The reproduction is possibly targeting bigger hoaxes in the society.

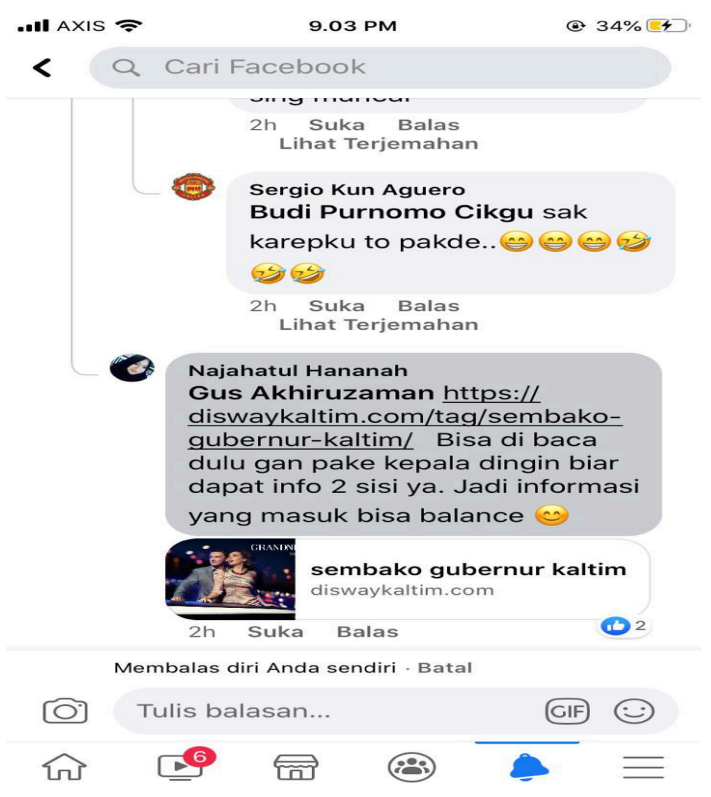

Figure 5: Informant Hana shows the reliable source after looking a hoax shared by an anonymous account in a Facebook group 
Facebook has various features that enable people to interact while using the application. Students as the agent of change expected to bring innovations through their new thoughts and behaviors that are transmitted to the society. The ability of students' media literacy could vary as some informants tried to take a role and educate the environment while receiving hoaxes information. But there were also a few informants who decided to do nothing because there were already another member of the community/group who has been providing reliable sources of news.

\section{Conclusion}

Looking at the results of this study, it can be concluded that:

1. The majority of informants decided not to share the news that they got when the source was not reliable enough. They tended to keep it to themselves or discuss it with their closest family, friends or colleagues. This study found that the majority of informants had good media literacy skills by trying to be critical of the news that they found on social media.

2. Informants had the ability to access the information they received and able to see the level of accuracy, quality and urgency of the information. The students decided to not to share the information to society when the information is not accurate or reliable.

\section{Acknowledgements}

The authors would like to acknowledge the Ministry of Research, Technology, and Higher Education for financial support through National Competitive Funding for Junior Researcher year 2020 Grant Number 087/AMD/SP2H/LT/DRPM/2020; 374/LL11/KM/2020; 01.7/023/KP/LPPM/UNU-KT/IV/2020.

\section{References}

[1] https://tekno.kompas.com/read/2018/02/22/16453177/berapa-jumlah-pengguna-internetindonesia.

[2] Potter, W. James. 2005.Media Literacy Third Edition.Los Angeles. Sage Publication

[3] Potter, W. James. 2005.Media Literacy Third Edition.Los Angeles. Sage Publication

[4] Silverblatt, A 2001. Media Literacy: Keys to Interpreting Media Messages. Westport, CT:

Praeger

[5] https://www.centerfornewsliteracy.org/what-is-news-literacy/

[6] https://mastel.id/hasil-survey-wabah-hoax-nasional-2019/

[7] Hartono. Post Truth: Melawan Hoax dengan Fact Checking. 2018. Fisip Untirta

[8] Neuman, Lawrence (2000). Social Research Methods: Qualitative and Quantitative Approaches, $4^{\text {th }}$ Edition. Boston, Allyn and Bacon

[9] Sutopo, HB (2000). Metode Penelitian Sosial Kualitatif. Solo, UNS Press.

[10] https://dewanpers.or.id/berita/detail/875/Dewan-Pers-Beberkan-Ciri-Ciri-Berita-Hoax[ 